\title{
IKÄASUMISEN ODOTUKSISTA JA UUSISTA KÄYTÄNNÖISTÄ
}

\author{
Paula Vasara: YTT, tutkijatobtori, Ikääntymisen ja hoivan tutkimuksen buippuykesikkëo, Iyväskylän yliopisto \\ paula.vasara@jyu.fi
}

Janus vol. 29 (2) 2021, 176-181

Nyky-yhteiskunnassa ikääntyvän arjen elämän järjestelyitä ovat muovaamassa monenlaiset ikä-, asumis- ja hoivapolitiikan linjaukset ja käytännöt. Erilaisista odotuksista, suosituksista ja jopa yksilölle asetetuista vaateista on tullut arkipäivää; moderni hyvinvointivaltio vaatii ikääntyvältä aktiivisuutta, omatoimisuutta, vastuun ottamista, ennakointia sekä varautumista tulevaan. Mikään näistä ei sinänsä ole yksinomaan huono asia - itse kunkin on hyvä välillä pysähtyä miettimään sitä, mikä elämässä koetaan merkitykselliseksi ja mitä ikääntyminen ja hyvä vanhuus itse asiassa voisivat omalla kohdalla tarkoittaa. Ongelmallisia näistä vaateista tulee silloin, kun ne heijastuvat käytäntöihin, joita vasten kansalaisen moraalista arvoa ja kyvykkyyttä peilataan.

Asumisen järjestelyt ovat yksi niistä elämän kehyksistä, joissa kiteytyvät monella tapaa erilaiset yhteiskunnan vaateet ja yksilön asema suhteessa niihin. Omaa kotia, itsemääräämisoikeutta ja itsenäisyyttä arvostetaan ja sitä pyritään kunnioittamaan mahdollisimman pitkälle. Suomalaiselle asumiselle tyypillistä on pitkäaikaisuus ja omistaminen (SVT 2015), mutta pysyvyys ei kuitenkaan tarkoita samanlaisuutta: vain harvoin asumisen ratkaisut pysyvät tismalleen samankaltaisina koko elämänkulun ajan, ja vähintäänkin ko- kemus näistä järjestelyistä muuttuu ajan kuluessa (Vasara 2020).

Ikääntyneiden asuminen on kuitenkin jotain, joka on jo pitkään tunnistettu erityistä huomiota vaativaksi asiaksi hyvinvointivaltion politiikassa. Asumispolitiikan kehitysohjelmissa ikääntyneet ovat saaneet oman ohjelmansa (YM 2013) ja hyvän ikääntymisen turvaamiseksi on laadittu useita laatusuosituksia (STM 2001; 2008; 2013; 2017; 2020), joiden esille nostamia asioita on kirjattu myös lakiin (Laki ikääntyneen väestön toimintakyvyn tukemisesta sekä iäkkäiden sosiaali- ja terveyspalveluista 980/2012). Lisäksi syksyllä 2020 julkaistiin poikkihallinnollinen ikäohjelma (STM 2020).

Näitä ohjelmia ja suosituksia yhdistää ajatus siitä, että on turvattava ikääntyneen mahdollisuus asua omassa kodissaan palvelujen turvin mahdollisimman pitkälle. Tuoreimmat versiot korostavat ikääntyvän omaa toimijuutta ja vastuuta painottamalla tarvetta ennakoida omia tulevia asumisen ja mahdollisen hoivan tarpeita - riittävän varhain.

\section{JuLKinen vastuU}

Viimeisimpiä ikääntyneiden asumispolitiikkaan liittyviä dokumentteja on sosiaali- ja terveysministeriön keväällä 
2020 julkaisema raportti Kohti ikäystävällistä yhteiskuntaa. Iäkkäiden henkilöiden palvelujen uudistamistyöryhmän raportti (STM 2020). Työryhmän ehdotukset keskittyivät lähinnä nimeämään niitä kipukohtia, jotka ovat ajankohtaistuneet suurempien kehityslinjojen, markkinoistumisen, yksityistymisen ja refamilisaation (ks. esim. Szebehely 2018) vahvistumisen myötä, eivätkä ne sinänsä näytä yllättäneen ketään.

Yksi näistä raportissa mainituista ikääntymiseen liittyvistä kipukohdista linkittyy vahvasti asumispolitiikkaan. 2000-luvulla on saatu todistaa paikoillaan vanhenemisen politiikan vahvistumista ja kotihoidon kohdentumista yhä tiukemmin vain eniten tarvitseville (ks. esim. Kehusmaa \& Hammar 2019; Kröger ym. 2019; STM 2019; THL 2017). Lisäksi yksi rakenteellisista pulmista on soveliaiden asumisratkaisujen puute (YM 2013). Uudenlaisia ikäasumisen ratkaisuja on selvitelty (ks. esim. Jolanki ym. 2017), mutta pääsääntöisesti omassa tavanomaisessa kodissa asutaan käytännössä niin pitkään kuin mahdollista, minkä jälkeen ikääntynyt siirtyy viimeisinä elinvuosinaan ympärivuorokautisen palveluasumisen piiriin (Aaltonen ym. 2017).

Vanhuspalvelujen saatavuudesta, riittävyydestä ja oikea-aikaisuudesta sekä ylipäätään omassa kodissa asumisen jatkamisesta viimeiseen asti on alettu käydä yhä kovaäänisempää keskustelua. STM:n (2020) raportti nostaakin esille tarpeen monimuotoistaa ikäihmisten asumista. Yhdeksi ratkaisuksi tarjotaan niin kutsuttua välimuotoista asumista.

Ympäristöministeriön määrittelyn mukaan käsitteellä välimuotoinen asumi- nen kuvataan sellaisia asumisratkaisuja jotka ovat ikäspesifejä ja sijoittuvat itsenäisen tavallisen asumisen sekä tehostetun palveluasumisen väliin. Asumisen tulee täyttää tavallisen asunnon tunnuspiirteet, mutta se voi sisältää erilaisia kotona asumista tukevia palveluita. Usein siihen liitetään myös jonkinlainen yhteisöllinen elementti. (YM 2020, 19.)

Näin määriteltynä käsitteenä välimuotoinen asuminen kuulostaa nopeasti ajatellen hyvältä: omassa kodissaan voi asua niin halutessaan, mutta oma koti ei olekaan ainoa vaihtoehto tehostettuun palveluasumiseen siirtymiselle. Retoriikka on itse asiassa melko nerokasta; se tuo mieleen aiempien vuosikymmenten käytännöt, esimerkiksi vanhustentalot tai muut vastaavat kevyemmän tuen ikäasumisen muodot, joista 2000-luvulla on pyritty pääsemään eroon. Se erottautuu myös selkeästi laitoksesta; suurelle yleisölle maalataan kuva tilanteesta, missä esimerkiksi turvattomuutta kokevilla, muisti- tai monisairailla ikääntyvillä olisi mahdollisuus valita itselle mieluinen ikäasumisen muoto, jossa riittävää ja oikeaaikaista tukea olisi saatavilla.

\section{VÄLISSÄ OLEMINEN}

STM:n uudistustyöryhmän raportin ehdotuksesta välittynyt kuva ei kuitenkaan kerro koko totuutta, sillä nykyinen politiikkasuositus pyrkii erottamaan asumisen hoivasta, millä on suoria vaikutuksia iäkkäälle koituviin kustannuksiin (ks. esim. Hoppania ym. 2016; THL 2017a; THL 2017b). Käytännössä välimuotoinen asuminen voi itse asiassa olla mitä tahansa: se voi olla 
esimerkiksi täysin tavallinen asunto, johon asukas itse omatoimisesti hankkii tarvitsemansa palvelut. Se ei käytännössä näytä olevan oikeastaan mitään muuta kuin kiertoilmaus sille, että ikääntyvä itse huolehtii itselle soveliaan kodin ja hoivan järjestelyt. Raportissa väläytellään jopa mahdollisuutta siihen, että välimuotoinen asuminen tulevaisuudessa määritettäisiin tavanomaiseksi asumiseksi, minkä järjestämisvastuu poistuisi kunnilta.

Nämä yhteiskuntapoliittiset kehityskulut, paikoillaan vanhenemisen politiikan yksipuoleinen painottaminen ja palveluiden kohdentaminen vain niitä eniten tarvitseville, ovat huolestuttavia. Yhä enemmän vastuuta jää yksilölle, kun yhteiskunnan turvaverkon silmukat harventuvat. Niin kutsutuilla hyväosaisillakin alkaa olla vaikeuksia luovia palveluviidakossa. Lisäksi jo nyt voidaan nähdä, että on syntynyt väliinputoajien joukko: osa ikääntyvistä on liian hyväkuntoisia päästäkseen julkisen avun piiriin, mutta ei kuitenkaan selviydy arjesta täysin itsenäisesti, eikä toisaalta kykene hankkimaan tarvitsemaansa apua.

Ratkaisuksi ehdotetaan usein kolmannen sektorin toimijoita tai markkinoita läheisavun rinnalle. Nämä ovatkin alkaneet tuottaa yhä lisääntyvässä määrin erilaisia hoiva- ja tukipalveluita. Valitettavasti kustannukset nousevat näissä usein pulmaksi heikoimmassa asemassa oleville. Myös alueelliset erot ovat suuria eikä ole mitään takeita siitä, että pienellä syrjäisellä kunnalla apua olisi saatavilla kohtuuhinnalla. Ikääntyvä voikin löytää itsensä todellisesta ahdingosta elämänsä loppupuoliskolla - tahtotila ei tässä takaa onnistumista.

\section{UUSIA TUULIA}

Markkinat ja yksityinen yrityssektori ovat tuoneet ikäasumisen kentälle lisää asumisen vaihtoehtoja: senioritalot ovat uusia, esteettömiä taloja,jotka sijaitsevat lähellä palveluita. Usein muuttopäätös kehystetään jollakin tapaa panostukseksi elämänlaatuun ja hyvinvointiin, vanhasta epäsopivasta ja työläästä asumismuodosta eroon pääsemiseksi ja aktiiviseen vanhenemiseen (ks. esim. WHO 2002; Bengtson \& Settersten 2016) panostamiseksi. Lyhyesti sanottuna muuttajasta rakennetaan harkitseva ja rationaalinen kuluttaja, joka ennakoi ja varautuu tulevaisuuteen - moraalisesti hyvä kansalainen.

Yhä vahvemmin kuluttajuutta ja yksilön valinnan mahdollisuuksia korostavassa yhteiskunnassa tilaa uudenlaisille tervetulleille ratkaisuille on jo otettu, mutta rahakaan ei ratkaise kaikkea. Pikemminkin markkinavetoisten ratkaisujen lisääntyminen ja keskinäinen kilpailu ovat johtaneet tilanteeseen, missä haavoittuvammassa asemassa olevien ikääntyneiden valinnan mahdollisuudet saattavat entisestään kaventua. Tietoa, ohjausta ja tukea ratkaisujen tekemiseksi ei ole riittävästi tarjolla. Lisäksi esimerkiksi asuntomarkkinoiden toimivuuteen liittyy paljon haasteita, jotka pitkälti juontuvat alueellisiin eroihin ja joita on vaikea ratkaista ainakaan lyhyellä aikavälillä.

\section{VASTAREAKTIOITA}

Ikääntyneiden omista aloitteista rakentuneita erilaisia senioriasumisen ratkaisuja voidaan pitää vastareaktiona vallitsevalle ikä- ja asumispolitiikalle. 
Omalla tavallaan ne edustavat kansalaisten politisoitumista ja ruohonjuuritason liikettä. Ne saavat usein voimaa hyvin konkreettisista arjessa koetuista pulmatilanteista, joihin lähdetään etsimään ratkaisuja. Omalla tavallaan ne asettuvat tärkeällä tavalla vastalauseeksi vallitsevalle julkiselle politiikkasuositukselle sekä markkinavoimien ohjaamille voittoa tavoittelevien yritysten pyrkimyksille ohjata ikä- ja erityisasumista yhä pidemmälle uusliberalismin markkinavoimien armoille.

Kolmannen sektorin toimijoiden ja ruohonjuuritason liikkeiden toiminnasta ehkä tunnetuin esimerkki Suomessa on helsinkiläinen Loppukiri (Loppukiri 2020), joka edustaa yhteisöllistä asumista sanan vahvassa muodossa. Näiden asumismuotojen juuret ovat menneiden vuosikymmenten yhteisöasumisessa, missä yhteisöllisyys on ollut omalla tavalla pakottavaa ja vaatinut asukkaalta vahvaa sitoutumista yhteiseen ja yhdessä tekemiseen. Näiden rinnalle on viime vuosina alkanut ilmaantua uudenlaisia, kevyemmällä tavalla yhteisöllisyyttä tavoittelevia senioriasumisen muotoja ja ikäkortteleita.

Hyvä esimerkki on muun muassa Keski-Suomessa perustettu voittoa tavoittelematon asumisoikeusyhdistys JASO (Jaso 2020), joka pyrkii rakennuttamaan ikääntyville esteettömiä koteja hyvien palveluiden äärelle. Asunnot sijoitetaan lähelle peruspalveluita ja ne suunnitellaan niin, että tilaratkaisuissa huomioidaan sekä sujuva itsenäinen arki että myös kotiin tuotavien palvelujen mahdollisuus. Lisäksi esimerkiksi voittoa tavoittelemattoman yhdistyksen mahdollisuutena on vapaarahoitteisten asuntojen sijasta tarjota asumisoikeus- asumista, mikä voi mahdollistaa muuttamisen myös heille, joilla taloudelliset resurssit ovat vähäisempiä.

Nämä esimerkit ovat kiinnostavia myös tutkimuksen kannalta. Jyväskylän yliopiston Ikääntymisen ja hoivan tutkimuksen huippuyksikössä (CoE AgeCare) Ahava) tärkeänä tutkimuskohteena ovat erilaiset avun ja tuen ratkaisut ja senioriasumista onkin tarkasteltu myös siitä näkökulmasta, miten nämä uudenlaiset ikäasumisen vaihtoehdot kykenevät vastaamaan ikääntyvien toiveisiin ja odotuksiin turvallisesta ja sujuvasta arjesta sekä hyvästä vanhenemisesta.

Ahava-tutkimuksen alustavat tulokset viittaavat siihen, että uudenlaiset asumisen vaihtoehdot ovat tervetulleita ikääntyvien itsensä näkökulmasta. Oman asumisen järjestämisessä rahoitus, tilaratkaisut ja sijainti ovat tärkeitä, mutta olennaista on myös turvallisuuden ja arjessa selviytymisen tunteen tukeminen. Tämä näytti yhteisöllisyyteen rohkaisevassa senioritalossa pohjaavan monenlaisiin, usein melko pieniin asioihin. Esimerkiksi tutkimuskohteessamme oli rakennettu niitä paikkoja, joissa niin sanotut satunnaiset kohtaamiset olivat mahdollisia. Oli niitä tilaisuuksia, joihin oli helppo osallistua, niin fyysisesti kuin muutoinkin. Oli se vähintään kasvoiltaan tuttu naapuri, jolle nyökättiin käytävässä, ja se rouva, jonka kanssa yhdessä nautittiin päiväkahvit. Pelkkä ajatus siitä, että joku tulee katsomaan, jos minua ei pariin päivään näy, ja tilaisuus kysyä neuvoa naapurilta tai toiminnanohjaajalta, riittivät pitkälle.

Ilmiön voisi ehkä sanoittaa osallisuudeksi ja nähdyksi tulemisen kokemukseksi. Vaikuttaa siltä, että yhteisöllisyyttä 
painottavien senioritalojen menestys perustuu osaltaan niiden kykyyn vastata kevyempiin, epämääräisempiin ja usein sanoittamatta jääviin tuen tarpeisiin. Kun tilat mahdollistavat erilaisia kohtaamisia ja yhteistä toimintaa on tukemassa sitä koordinoiva henkilö, matalan kynnyksen osallisuus mahdollistuu. Myönteisten kokemusten myötä omaan arkeen saadaan varmuutta siitä, että asiat kyllä järjestyvät.

Oli myös tärkeä huomata, miten yksilön oma toimijuus ja mahdollisuus säädellä omaa osallistumista vaikuttivat asumisen kokemukseen. Omaa kotia ja omaa rauhaa arvostettiin, mutta seinien ei haluttu vangitsevan sisäänsä. Yhteisöllisyyteen rohkaiseva, ei pakottava senioritalo mahdollisti kohtaamisia, mutta se antoi myös tilaa sille, että oven saattoi sulkea perässään. Silti ajatus siitä, että jossain vaiheessa joku kuitenkin koputtaisi ovelle ja kysäisisi "onko kaikki hyvin", oli se tekijä, joka mahdollisti turvallisuuden tunteen.

\section{LOPUKSI}

Yksi parhaiten mieleen jääneistä kohtaamisista senioritalossa oli rouva, joka kertoi iloisena veriarvojen parantuneen, painon laskeneen ja yleiskunnon kohenneen senioritaloon muuton jälkeen - ja kaikki tämä vain siksi, että oli vihdoinkin paikka, jossa oli mielekästä tekemistä tarjolla ja johon hänen oli helppo päästä mukaan liikuntarajoitteisenakin. Tämä kertoo osaltaan siitä, miten tärkeä elämän kehys asuminen on - se sekä mahdollistaa että sulkee pois jotain vaihtoehtoja.
Hyvään elämään kuuluu vanhanakin mielekäs tekeminen, osallisuus ja turvallinen arki. Mieluisa tekemisen taso voi vaihdella elämäntilanteen mukaan, mutta seinien sisään tiivistynytkin elämä voi saada uuden muodon elämän loppupuoliskolla, kun sille tarjotaan sopivat puitteet. Vaikka kronologisen iän lisääntymiseen usein liittyykin jotain terveyden ja toimintakyvyn heikkenemistä, ikään liitetyt muutokset ovat lopultakin ennakoimattomia ja hyvin erilaisia eri yksilöillä. Viimeaikaiset tutkimukset ovat myös ilahduttavasti todentaneet, että nämä ikämuutokset tapahtuvat yhä myöhemmässä vaiheessa, mikä lisää hyvien vuosien määrää (Bengtson \& Settersten 2016; Koponen ym. 2018; Gerec 2020).

Harva kaipaa sitä, että julkinen valta säätelisi kovinkaan tarkasti omaan arkeen, kotiin tai yksityisen piiriin kuuluvia asioita. Yksilöllisyyttä ja yksityisyyttä arvostetaan - mutta kaikella on rajansa. Näitä rajoja voidaan koetella esimerkiksi senioritalossa tai ottamalla omaan arkeen käyttöön sellaisia pieniä käytäntöjä, jotka hyväksi havaitaan. Hyvät esimerkit ovat aina innoittavia ja niille on tarve, kun pohditaan sitä, mitä hyvä vanheneminen oikeastaan tarkoittaa ja miten se on suhteessa fyysiseen paikkaan.

\section{KirjallisuUs}

Aaltonen, Mari \& Forma, Leena \& Pulkki, Jutta \& Raitanen, Jani \& Rissanen, Pekka \& Jylhä, Marja (2017) Changes in older people's care profiles during the last 2 years of life, 1996-1998 and 2011-2013: a retrospective nationwide 
study in Finland. BMJ Open 2017; e015130. https://doi.org/10.1136/bmjopen-2016-015130

Bengtson, Vern L. \& Settersten, Jr. Richard A. (toim.) (2016) Handbook of Theories of Aging. $3^{\text {rd }}$ edition. New York: Springer.

Gerec Tiedeuutiset (2020) Iäkkäät ihmiset ovat nuortuneet: fyysinen ja älyllinen toimintakyky on parantunut 30 vuodessa merkittävästi. https://www.gerec. fi/en/iakkaat-ihmiset-ovat-nuortuneetfyysinen-ja-alyllinen-toimintakyky-onparantunut-30-vuodessa-merkittavasti/. Luettu 2.10.2020.

Hoppania, Hanna-Kaisa \& Karsio, Olli \& Näre, Lena \& Olakivi, Antero \& Sointu, Liina \& Vaittinen, Tiina \& Zechner, Minna (2016) Hoivan arvoiset. Vaiva yhteiskunnan ytimessä. Helsinki: Gaudeamus.

Jaso (2020) Jason toimintaperiaatteet. https://www.jasoasunnot.com/jaso-yhdistys/. Luettu 2.10.2020.

Jolanki, Outi \& Leinonen, Emilia \& Rajaniemi, Jere \& Rappe, Erja \& Räsänen, Tiina \& Teittinen, Outi \& Topo, Päivi (2017) Asumisen yhteisöllisyys ja hyvä vanhuus. Valtioneuvoston selvitys- ja tutkimustoiminnan julkaisusarja 47. Helsinki:Valtioneuvoston kanslia.

Kehusmaa, Sari \& Hammar, Teija (2019) Kahdeksan faktaa vanhuspalvelujen tilasta. https://thl.fi/fi/-/8-faktaa-vanhuspalvelujen-tilasta. Luettu 17.10.2019.

Koponen, Päivikki \& Borodulin, Katja \& Lundqvist, Annamari \& Säksjärvi, Katri \& Koskinen, Seppo (toim.) (2018) Terveys, toimintakyky ja hyvinvointi Suomessa. FinTerveys 2017 -tutkimus. Raportteja 4. Helsinki: Terveyden ja hyvinvoinnin laitos.

Laki ikääntyneen väestön toimintakyvyn tukemisesta sekä iäkkäiden sosiaali- ja terveyspalveluista 980/2012.

Loppukiri (2020) Asukasyhteisö Helsingin Loppukiri - maailmaan yhdessä ja ikkunat auki. https://www.loppukiri.com. Luettu 2.10.2020

Sosiaali- ja terveysministeriö (STM) (2017) Laatusuositus hyvän ikääntymisen turvaamiseksi ja palvelujen parantamiseksi. Sosiaali- ja terveysministeriön julkaisuja 6. Helsinki: Sosiaali- ja terveysministeriö ja Kuntaliitto.
Sosiaali- ja terveysministeriö

(STM) (2019) Iäkkäiden palvelujen uudistaminen. https://stm.fi/ hanke?tunnus $=$ STM025:00/2019. Luettu 31.10.2019.

Sosiaali- ja terveysministeriö (STM) (2020) Laatusuositus hyvän ikääntymisen turvaamiseksi ja palveluiden parantamiseksi 2020-2023. Tavoitteena ikäystävällinen Suomi. Sosiaali- ja terveysministeriön julkaisuja 29. Helsinki: Sosiaali- ja terveysministeriö ja Suomen Kuntaliitto.

Sosiaali- ja terveysministeriö (STM) (2020) Kansallinen ikäohjelma vuoteen 2030. Tavoitteena ikäkyvykäs Suomi. Sosiaalija terveysministeriön julkaisuja 31. Helsinki: Sosiaali- ja terveysministeriö.

Suomen virallinen tilasto (SVT) (2015) Asunnot ja asuinolot. Tilastokeskus. http://www.stat.fi/til/asas/2015/ asas_2015_2016-05-24_tie_001_fi.html. Luettu 18.10.2019.

Szebehely, Marta (2018) Nordic eldercare in the time of privatization: Experiences from Sweden. Luento Ikääntymisen ja hoivan tutkimuksen huippuyksikön aloitusseminaarissa. Helsinki 2.3.2018.

Terveyden ja hyvinvoinnin laitos (THL) (2017a) Kotihoito ja sosiaalihuollon laitos- ja asumispalvelut 2016. Tilastoraportti 42. Helsinki: Terveyden ja hyvinvoinnin laitos.

Terveyden ja hyvinvoinnin laitos (THL) (2017b) Sosiaalihuollon laitos- ja asumispalvelut 2015. Suomen virallinen tilasto. Tilastoraportti 2. Helsinki: Terveyden ja hyvinvoinnin laitos.

Vasara, Paula (2020) Väistämättömyyksiä ja valintoja. Kertomuksia ikäihmisten asumispolulta. JYU Dissertations 212. Jyväskylä: Jyväskylän yliopisto.

Ympäristöministeriö (YM) (2013) Ikääntyneiden asumisen kehittämisohjelma vuosille 2013-2017. Ympäristöministeriö. http://www.ym.fi/download/ noname/\%7BEAF4ED7E-F582-414E8A33-1A9BC0067707\%7D/37430. Luettu 19.8.2014.

Ympäristöministeriö (2020) Ikääntyneiden välimuotoisen asumisen tilanne $\mathrm{ja}$ tulevaisuuden tarpeet. Ympäristöministeriön julkaisuja 8. Helsinki:Ympäristöministeriö. 